\title{
KREDIBILITAS TENAGA PERPUSTAKAAN SMAN 1 SINDANG KAB. INDRAMAYU
}

\author{
Tursi $^{1}$, Prijana ${ }^{2}$, Asep Saeful Rohman ${ }^{3}$ \\ ${ }^{1}$ SMP IT Al Haraki, ${ }^{2,3}$ Program Studi Ilmu Perpustakaan Universitas Padjadjaran \\ 11Tursi.diipunpad11@gmail.com,2prijanafikom@gmail.com, \\ 3asep.saefulr@gmail.com
}

ABSTRACT - This research discussed about the credibility of Library staff at SMAN 1 Sindang, Indramayu. This research used Credibility Theory from Hovland, Janis, and Kelley (1953). The purpose of this research is to know the credibility of library staff trough three components:attractiveness, skill and trust. The method used in this research is qualitative method with case study. Data were obtained from observations, interviews, and literature searches. The informant are eight people include the head of library, two library staffs, and five students. The result of this research shows the library staffs at SMAN 1 Sindang have good enough credibility. The library staff attraction consist of two factors; 1) Internal factor that is application of instructional technique and human realtions in communicating with students that produce a good interpersonal communication, 2) External factor is promotion that library staffs did such as rewarding and library socialization. Library staffs skill at SMAN 1 Sindang include management, service, developing of library staff sistem based on management competence, information management competence, education competence, personality competence, social competence, and profession development competence. It can be concluded the attractiveness and skill is to be related each other to build trust that continuously produce library staffs credibility at SMAN 1 Sindang. Library staff credibility in SMAN 1 Sindang was influenced too by educational factor, experience, and communication style. Hopefully, this research can be reference for the government to keep upgrading the human resources at school library especially SMAN 1 Sindang.

Key words: School library, Library staffs, Credibility

ABSTRAK - Penelitian ini menggambarkan kredibilitas tenaga perpustakaan SMA 1 Sindang, Indramayu. Penelitian ini menggunakan teori kredibilitas dari Hovland, Janis dan Kelley (1953).
Tujuan penelitian ini ialah untuk mengetahui kredibilitas tenaga perpustakaan melalui tiga komponen: daya tarik, keahlian dan kepercayaan. Metode penelitian yang digunakan dalam penelitian ini ialah metode kualitatif melalui studi kasus. Data penelitian dihasilkan dari observasi, wawancara, dan studi literatur. Informan adalah 8 orang termasuk kepala perpustakaan, 2 tenaga perpustakaan dan 5 siswa. Hasil penelitian ini menunjukkan bahwa tenaga perpustakaan SMA 1 Sindang memiliki kredibilitas yang cukup bagus. Daya tenaga perpustakaan terdiri dari 2 faktor; 1) faktor internal yang diaplikasikan dari teknik instruksional dan hubungan manusia dalam komunikasi diantara siswa yang diproduksi melalui komunikasi interpersonal, 2) faktor eksternal ialah promosi yang dilakukan tenaga perpustakaan melalui penghargaan dan sosialisasi perpustakaan. Keahlian tenaga perpustakaan SMA 1 Sindang termasuk manajemen, pelayanan, pengembangan sistem tenaga perpustakaan berdasarkan manajemen kompetensi, manajemen kompetensi informasi, kompetensi pendidikan, kompetensi kepribadian, kompetensi sosial, dan pengembangan kompetensi profesi. Dapat ditarik kesimpulan bahwa daya tarik dan keahlian menjadi saling terhubung satu sama lain untuk membangun kepercayaan yang diproduksi terus menerus oleh kredibilitas tenaga perpustakaan SMA 1 Sindang. Kredibilitas tenaga perpustakaan di SMA 1 Sindang dipengaruhi juga melalui faktor pendidikan, pengalaman, dan gaya komunikasi. Harapannya, penelitian ini dapat menjadi rujukan bagi pemerintah untuk meningkatkan sumber daya manusia di Perpustakaan Sekolah khususnya SMA 1 Sindang.

Kata kunci: Perpustakaan sekolah, tenaga perpustakaan, kredibilitas. 


\section{PENDAHULUAN}

Perpustakaan sekolah merupakan salah satu sarana penting dalam penyelenggaraan pendidikan dan pengajaran di sekolah. Melalui perpustakaan siswa dapat memanfaatkan koleksi sebagai sumber informasi sebagai penunjang kegiatan pembelajaran. Adapun tujuan keberadaan perpustakaan sekolah adalah menyediakan pusat sumber belajar sehingga dapat menambah wawasan dan pengetahuan siswa, mengembangkan dan meningkatan minat baca, belajar menerapkan kegiatan literasi informasi, hingga pengembangan bakat serta kemampuan peserta didik.

Sebagai salah satu sarana pendidikan penunjang kegiatan belajar siswa, perpustakaan sekolah memegang peranan yang sangat penting dalam memacu tercapainya tujuan pendidikan di sekolah. Mengingat pentingnya keberadaan perpustakaan dalam suatu institusi pendidikan, pemerintah dalam Undang-undang Sistem Pendidikan Nasional Tahun 2003 dalam pasal 45 ayat 1 mengatakan bahwa setiap satuan pendidikan formal dan nonformal harus menyediakan sarana dan prasarana yang memenuhi keperluan pendidikan sesuai dengan pertumbuhan dan perkembangan potensi fisik, kecerdasan intelektual, sosial, emosional, dan kejiwaan peserta didik.

Selaras dengan pentingnya perpustakaan bagi suatu sekolah, begitu juga dengan tenaga perpustakaan yang penting bagi suatu perpustakaan. Setiap perpustakaan harus memiliki sekurang-kurangnya satu tenaga perpustakaan sekolah/madrasah yang berkualifikasi SMA atau yang sederajat dan bersertifikat kompetensi pengolahan perpustakaan sekolah/madrasah dari lembaga yang ditetapkan oleh pemerintah. Perpustakaan juga berkewajiban memberikan kesempatan untuk pengembangan sumber daya manusia melalui pendidikan formal dan non formal ketenagaperpustakaan.

Dari segi SDM (sumber daya manusia) perpustakaan SMAN 1 Sindang Kab. Indramayu terdiri dari kepala perpustakaan dan dua tenaga perpustakaan. Untuk sekelas perpustakaan sekolah memiliki kepala dan dua tenaga perpustakaan di Kab. Indramayu sendiri masih jarang. Kebanyakan perpustakan-perpustakaan sekolah di Kab. Indramayu dikelola oleh guru yang ditugaskan di perpustakaan. Sedangkan di perpustakaan SMAN 1 Sindang Kab. Indramayu sendiri, meski kepala perpustakaannya tidak memiliki backgorund ilmu perpustakaan setidaknya dua orang tenaga perpustakaannya memiliki kompetensi dalam bidang pengelolaan perpustakaan.

Saat ini perpustakaan SMAN 1 Sindang Kab. Indramayu dijadikan percontohan untuk perpustakaan sekolah di Kab. Indramayu. Selain itu perpustakaan SMAN 1 Sindang Kab. Indramayu sendiri telah menjuarai beberapa lomba baik dalam tingkat kabupaten maupun provinsi. Prestasi terbaru perpustakaan SMAN 1 Sindang adalah sebagai wakil Kab.Indramayu dalam Penilaian Perpustakaan Sekolah tingkat Provinsi Jawa Barat tahun 2015. Meski demikian, dikatakan Saptarini, selaku kepala perpustakaan SMAN 1 Sindang Kab. Indramayu, 
bahwa di masa depan pengembangan perpustakaan akan selalu ditingkatkan, mengingat perpustakaan merupakan sumber utama pembelajaran di sekolah (Saptarini, 2016).

Diharapkan perpustakaan SMAN 1 Sindang Kab. Indramayu semakin berkembang dengan lebih baik. Apalagi perpustakaan SMAN 1 Sindang Kab. Indramayu tiga dari sekolah yang berada di Kab. Indramayu yang telah dikelola oleh seseorang yang memang memiliki latar belakang ilmu perpustakaan melalui pendidikan formal yang tentunya lebih mengetahui dan memahami kebutuhan apa saja yang ada di perpustakaan seperti pelayanan, manajemen maupun pemasarannnya serta promosi perpustakaan.

Untuk promosi yang telah dilakukan perpustakaan SMAN 1 Sindang Kab. Indramayu sendiri sebagian memang belum diterapkan oleh perpustakaan lain di kab. Indramayu. Seperti papan informasi mengenai buku terbaru dan populer yang dipasang di depan perpustakan diupayakan sebagai salah satu daya tarik untuk menarik minat baca siswa oleh tenaga perpustakaan. Selain itu bentuk promosi perpustakaan lainnya, yakni berupa pemberian reward atas peminjam dan pengunjung terbaik yang idenya didapat dari Liah melalui pelatihan yang diselenggarakan oleh pihak perpustakaan tingkat provinsi. Menurutnya, sampai sekarang dirasa efektif untuk menarik kunjungan siswa ke perpustakaan terutama untuk siswa baru kelas 10 (Liah, 2015).

Tentunya sekolah yang berkualitas harus dibarengi dengan faslitas yang berkualitas, termasuk perpustakaan di dalamnya karena seperti yang telah dijelaskan sebelumnya perpustakaan merupakan salah satu fasilitas penting di sekolah, begitu juga di SMAN 1 Sindang Kab. Indramayu yang kini menjadi rintisan sekolah bertaraf internasional. Selain itu untuk mewujudkan visi dan misi sekolah serta visi misi dari perpustakaan itu sendiri dibutuhkan dukungan berbagai aspek yang berkualitas termasuk kualitas dari tenaga perpustakaan. Kualitas dapat dilihat dari kredibilitas.

Kredibilitas komunikator dalam hal ini adalah tenaga perpustakaan, merupakan kemampuan seseorang atau suatu lembaga untuk menyampaikan pesan agar dapat diterima dengan baik oleh komunikan. Hovland, Janis dan Kelley menemukan tiga aspek yang mempengaruhi kredibilitas sumber yakni, kepercayaan (trustworthiness), keahlian (expertise), dan daya tarik (attractiveness) (Venus, 2009). Hovland dan Weiss mengatakan komponen kredibilitas yang paling penting terdiri dari keahlian (expertise) dan kepercayaan (trustworthiness) (Rakhmat, 2008 ).

Dengan latar pendidikan yang cukup serta pengalaman yang tidak sedikit, idealnya kedua tenaga perpustakaan SMAN 1 Sindang sudah mengantongi ketiga komponen kredibilitas tersebut. Apalagi perpustakaan melalui programprogram kerja serta layanan yang diberikan dan koleksi yang dimilikinya turut serta dalam menentukan keberhasilan proses pembelajaran di sekolah dan pelaksanaan kurikulum. Tenaga perpustakaan sekolah juga merupakan tenaga kependidikan yang ikut berperan dalam 
pencapaian prestasi siswa SMAN 1 Sindang sehingga keahlian, daya tarik dan kepercayaan merupakan hal mutlak yang harus dimiliki oleh seorang tenaga perpustakaan. Selain itu adanya kedekatan personal antara siswa dengan tenaga perpustakaan yang tercipta di perpustakaan SMAN 1 Sindang semakin menjadi penguat bahwa adanya kredibilitas yang terdapat pada dua tenaga perpustakaan SMAN 1 Sindang Kab. Indramayu. Karenanya, penulis tertarik untuk mengetahui bagaimana kredibilitas tenaga perpustakaan di SMAN 1 Sindang Kab. Indramayu. Berdasarkan pemaparan di atas, maka dapat dirumuskan tujuan penelitian sebagai berikut:

1. Untuk mengetahui bagaimana daya tarik tenaga perpustakaan perpustakaan SMAN 1 Sindang Kab. Indramayu

2. Untuk mengetahui bagaimana keahlian tenaga perpustakaan perpustakaan SMAN 1 Sindang Kab. Indramayu

3. Untuk mengetahui bagaimana kepercayaan tenaga perpustakaan di perpustakaan SMAN 1 Sindang Kab. Indramayu.

\section{TINJAUAN PUSTAKA}

Penelitian ini menggunakan Teori Kredibilitas Sumber (Source Credibility Theory) oleh Hovland, Janis, dan Kelley tahun 1953 dalam bukunya Communication and Persuasion. Teori ini menjelaskan bahwa seseorang dimungkinkan lebih mudah dibujuk (dipersuasi) jika sumber- sumber persuasinya (komunikator) cukup kredibel. Biasanya seseorang akan lebih percaya dan cenderung menerima dengan baik pesan-pesan yang disampaikan oleh orangorang yang memiliki kredibilitas di bidangnya (Venus, 2009).

Hovland, Janis dan Kelley menemukan tiga aspek yang mempengaruhi kredibilitas sumber yakni, keahlian (expertise), kepercayaan (trutsworthiness), dan daya tarik (attractiveness). Kredibilitas adalah seperangkat persepsi komunikate tentang sifat-sifat komunikator. Dalam definisi ini terkandung dua hal: 1) kredibilitas persepsi komunikate, tidak interns dalam diri komunikator; 2) kredibilitas berkenaan dengan sifat-sifat komunikator (Rakhmat, 2008 ). Keahlian adalah kesan yang dibentuk komunikate tentang kemampuan tenaga perpustakaan dalam hubungannya dengan topik yang dibicarakan dan dengan hal yang dilayankan. Faktor keahlian berhubungan dengan penilaian di mana sumber dianggap berpengetahuan, cerdas, berpengalaman, memiliki kewenangan tertentu dan menguasai skill yang bisa diandalkan (Venus, 2009).

\section{METODE PENELITIAN}

Penelitian mengenai kredibilitas tenaga perpustakaan di perpustakaan sekolah ini menggunakan metode penelitian kualitatif. Metode penelitian ini muncul karena terjadi perubahan paradigma dalam memandang suatu realitas/fenomena/gejala. Dalam paradigma ini realitas sosial dipandang sebagai suatu yang holistik/utuh, kompleks, dinamis, dan penuh makna. Paradigma yang demikian disebut paradigma positivisme, di mana dalam 
memandang gejala, lebih bersifat tunggal, statis dan konkrit. Paradigma postpositivisme mengembangkan metode penelitian kualitatif dan positivisme mengembangkan metode kuantitatif (Sugiyono, 2008 ).

Pemilihan metode kualitatif dilakukan karena menurut peneliti metode ini dianggap yang paling tepat untuk meneliti tentang Kredibilitas Tenaga Perpustakaan di SMAN 1 Sindang Kab. Indramayu. Pemilihan metode penelitian kualitatif dikarenakan penelitian ini dilakukan dalam natural setting. Selain itu dikarenakan dalam penelitan ini diperlukan pemahaman secara mendalam dalam memperoleh data. Data yang dikumpulkan berupa data deskriptif yang dialami oleh subjek. Data yang dikumpulkan lebih mengutamakan data langsung dengan menggunakan wawancara, observasi, dan studi dokumentasi. Sehingga metode penelitian kualitatif dipandang lebih tepat digunakan pada penelitian ini untuk dapat menjawab identifikasi masalah dan dapat mencapai tujuan dalam penelitian.

Yin mengatakan studi kasus terbagi menjadi metode-metode yang lebih spesifik, seperti: Pertama, descriptive, yaitu merupakan metode penelitian studi kasus yang fokus pada penguraian kasus yang sedang diteliti. Kedua, exploratory, yaitu penyelidikan secara mendalam misalnya peneliti yang terlibat langsung dengan obyek yang sedang diteliti. Ketiga, explanatory, yaitu peneliti memberikan keterangan-keterangan yang rinci dan penjelasan terhadap kasus yang diteliti (Yin, 2011). Dalam penelitian ini peneliti menggunakan studi kasus eksploratif. Pendekatan ini bertujuan menggali/mencari variabel-variabel atau faktorfaktor yang terdapat pada suatu fenomena/kondisi/setting sosial tertentu. Penelitian ini lebih menekankan pada penyelidikan dan mengeksplorasi komponenkomponen yang membentuk kredibilitas pada dua tenaga perpustakaan SMAN 1 Sindang Kab. Indramayu yang belum diketahui atau belum banyak informasi yang tersedia tentang hal tersebut yang dilakukan dari mulai melakukan observasi langsung, wawancara mendalam terhadap informan dan studi dokumentasi.

Adapun sumber informasi utama yang akan digunakan peneliti untuk mengumpulkan data adalah: dokumentasi, interview (open ended, wawancara terfokus, wawancara dengan pertanyaan yang terstruktur) dan observasi langsung. Menurut Yin, sumber data untuk penelitian ini terbagi menjadi dua, yaitu; 1) Data Primer, adalah berbagai informasi dan keterangan yang diperoleh langsung dari sumbernya, yaitu para pihak yang dijadikan informan penelitian. Informan penelitian yang menjadi sumber data primer ditentukan dengan metode purposive sampling. Kriteria penentuan informan penelitian didasarkan pada pertimbangan kedudukan/jabatan, kompetensi dan penguasaan masalah yang relevan dengan obyek penelitian. Informan dalam penelitian ini terdiri dari dua tenaga perpustakaan SMAN 11 Sindang, Kepala perpustakaan SMAN 1 Sindang, dan lima siswa.

2) Data Sekunder, adalah berupa studi pustaka di mana berbagai teori dan informasi yang diperoleh tidak langsung dari informan 
melainkan dari buku-buku, studi pustaka dan juga data lainnya yang relevan dengan kebutuhan dan tujuan penelitian (Yin, 2011).

Analisis bukti (data) dalam penelitian ini penulis menggunakan teknik penjodohan pola. Penjodohan Pola merupakan jenis strategi yang paling banyak digunakan oleh peneliti studi kasus. Logika ini membandingkan pola yang didasarkan atas empiris dengan pola yang diprediksi. Jika kedua pola ini memiliki persamaan, hasilnya dapat menguatkan validitas internal studi kasus yang bersangkutan. Sedangkan untuk uji validitas data dalam penelitian ini menggunakan; 1) triangulasi sumber, triangulasi ini dilakukan dengan membandingkan maupun menggabungkan data yang diperoleh melalui wawancara dari informan dengan informan lainnya atau juga pada informan yang sama dengan waktu dan alat yang berbeda. 2) triangulasi metode, triangulasi ini dilakukan untuk melakukan pengecekan terhadap penggunaan metode pengumpulan data, apakah informasi yang didapat dengan metode interview sama dengan metode observasi, atau apakah hasil observasi sesuai dengan informasi yang diberikan ketika diwawancarai. Objek dalam penelitian ini adalah kredibilitas tenaga perpustakaan SMAN 1 Sindang Kab. Indramayu.

\section{HASIL DAN PEMBAHASAN}

Daya tarik merupakan kesan pertama yang dirasakan oleh seseorang terhadap orang lain. Daya tarik merupakan salah satu penentu sesorang dalam mengambil keputusan. Daya tarik juga memiliki kaitan erat dengan tampilan sehingga tampilan seseorang menjadi hal pertama yang dilihat dan dinilai orang, begitu pula dengan tampilan yang coba ditampilkan oleh tenaga perpustakaan. Salah satu yang menjadi daya tarik dari tenaga perpustakaan SMAN 1 Sindang adalah berinteraksi dengan siswa dengan menggunakan cara-cara instruksional dengan pendekatan human relations. Instruksional berasal dari kata instruction artinya pembelajaran atau pengajaran yang merupakan bagian dari pendidikan. Dimana pendidikan sendiri memiliki bidang kajian yang lebih luas daripada instruksional (Yusuf, 2010).

Menurut Effendy, human relations memiliki arti hubungan manusia atau hubungan antar manusia. Ciri hakiki human relations bukan "human" dalam pengertian wujud manusia (human being), melainkan dalam makna proses rokhaniah yang tertuju kepada kebahagiaan berdasarkan watak, sifat, perangai kepribadian, sikap, tingkah laku dan aspek kejiwaan yang terdapat pada diri manusia (Effendy, 2009). Norman R.F. Maier dalam Effendy mengungkapkan bahwa, human relations dapat diusahakan untuk menghilangkan hambatanhambatan komunikasi, meniadakan salah pengertian dan mengembangkan segi konstruktif sifat tabiat manusia (Effendy, 2009).

Kondisi ini jika dilakukan secara terus menurus akan memunculkan kenyamanan dan kedekatan antara tenaga perpustakaan dan para siswa dengan suka rela dan tanpa paksaan datang ke perpustakaan. Tidak menutup kemungkinan setelah melalui kurun waktu tertentu akan terjalin suatu hubungan interpersonal diantara kedua 
belah pihak. Pemaparan mengenai kenyamanan dan kedekatan siswa dengan tenaga perpustakaan hingga memungkinkan adanya suatu hubungan interpersonal antar tenaga perpustakaan dan siswa bisa jadi dikarenakan komunikasi interpersonal yang digunakan tenaga perpustakaan setiap kali berinteraksi dengan para siswa.

Dari keseluruhan informan siswa, kesemuanya memang memiliki kedekatan dengan tenaga perpustakaan meski kadar kedekatan satu sama lainnya tidak sama. Tentunya kedekatan dengan tenaga perpustakaan di Perpustakaan SMAN 1 Sindang tidak terbentuk begitu saja. Seperti Dasilah dan Adit yang berawal dari seringnya mereka datang ke perpustakaan untuk meminjam buku, akhirnya menjadikan keduanya banyak berinteraksi dengan Hadi maupun Liah, sebagai tenaga perpustakaan. Dari interaksi tersebut terjadilah komunikasi yang awalnya memuat obrolan-obrolan ringan menjadi personal bahkan kadang kala bersifat curahatan.

Daya tarik lain yang berusaha dimunculkan oleh tenaga perpustakaan perpustakaan SMAN 1 Sindang adalah dengan diberikannya reward kepada peminjam terbaik kepada para siswa. Reward yang diberikan adalah berupa buku bacaan dan buku tulis yang disesuaikan dengan kecenderungan anak-anak terhadap topik tertentu. Liah yang bertanggung jawab terhadap pemberian reward ini akan melakukan observasi kecil-kecilan yang lakukan pada saat mendekati waktu pemberian reward yang biasanya diberikan setahun sekali pada saat upacara bendera pertama ditahun ajaran baru. Dana reward sendiri didapat dari sanksi keterlambatan anak-anak dalam pengembalian buku.

Sapta mengatakan, kegiatan pemberian reward sendiri menjadi salah satu program kerja perpustakaan yang diunggulkan oleh perpustakaan SMAN 1 Sindang (Sapta, 2015). Hal tersebut terlihat dari harapan Sapta untuk selalu meningkatkan kualitas maupun kuantitas dari reward itu sendiri. Selain itu masih belum banyaknya perpustakan sekolah di Kab. Indramayu yang menerapkan ide pemberian penghargaan ini bisa menjadi motivasi tersendiri untuk perpustakaan SMAN 1 Sindang dalam menjadi pelopor pemberian reward di perpustakaan sekolah.

Sejalan dengan pihak perpustakaan, Erna mengatakan bahwa pemberian reward membantu memberi motivasi kepada para siswa untuk datang ke perpustakaan (Erna, 2015). Ayu menambahkan adanya reward tersebut menandakan bahwa pihak perpustakaan mengapresiasi para siswa sebagai pengunjung dan menghargai siswa-siswa yang sering berkunjung (Ayu, 2015). Anne sendiri mengatakan kegiatan pemberian penghargaan ini bagus. Hal tersebut menurutnya karena bisa menarik simpati dari anak-anak yang awalnya jarang ke perpustakaan yang kemudian mengharuskan mereka untuk datang ke perpustakaan apabila ingin mendapatkan reward (Anne, 2015).

Kegiatan lain yang juga diharapkan menjadi daya tarik perpustakaan adalah dengan melakukan berbagai macam bentuk kegiatan promosi. Dalam hal ini melalui beberapa kegiatan 
promosi yang dilakukan perpustakaan SMAN 1 Sindang seperti memanfaatkan jejaring pertemanan di facebook sebagai tempat untuk berinteraksi dan media publikasi, mendisplay informasi buku populer di mading depan perpustakaan, mengadakan bazar buku murah diharapkan dapat menarik minat siswa untuk datang ke perpustakaan. Selain itu perpustakaan SMAN 1 Sindang juga rutin melakukan sosialisasi perpustakaan kepada siswa baru pada saat kegiatan Masa Orientasi Siswa (MOS).

Peraturan Menteri Pendidikan Nasional Republik Indonesia Nomor 25 Tahun 2008 Tentang Standar Tenaga Perpustakaan Sekolah/Madrasah sendiri mengungkapkan setidaknya tenaga pustakawan harus memiliki enam kompetensi yang terdiri dari: kompetensi manajerial, kompetensi pengelolaan informasi, kompetensi kependidikan, kompetensi kepribadian, kompetensi sosial, kompetensi pengembangan profesi. Dari keseluruhan kompetensi yang ada, penghargaan ini bisa menjadi motivasi tersendiri untuk perpustakaan SMAN 1 Sindang dalam menjadi pelopor pemberian reward di perpustakaan sekolah. Selain itu, kepala perpustakaan juga melakukan kegiatan planning, organizing, menyusun program kerja perpustakaan serta melakukan segala hal teknis yang ada di perpustakaan.

Diantara berbagai faktor yang mempengaruhi komunikasi interpersonal, faktor percaya adalah yang paling penting. Sejak tahap yang pertama dalam hubungan interpersonal, (tahap perkenalan), sampai pada tahap kedua (tahap peneguhan), percaya menentukan efektivitas komunikasi. Hal tersebut berdasarkan pengamatan peneliti selama berada di perpustakaan SMAN 1 Sindang bahwa hubungan yang terjalin antara siswa dan tenaga perpustakaan terjalin dengan baik. Hubungan interpersonal tersebut dapat dilihat dari interaksi kedua belah pihak yang tidak kaku dan tidak terkesan formal. Seperti yang juga telah dipaparkan dalam sub bab daya tarik, bahwa ke5 siswa yang menjadi informan kesemuanya memiliki rasa nyaman kepada tenaga perpustakaan meski kadarnya berbeda satu lain. Rasa nyaman ini bisa menjadi pondasi awal untuk memunculkan kepercayaan. Rasa nyaman juga yang menjadikan Dasilah dan Adit curhat kepada Liah. Bisa dikatakan keputusan kedua siswa ini untuk bercerita masalah pribadi kepada tenaga perpustakaan pasti telah melalui pertimbangan yang salah satunya adalah adanya rasa percaya keduanya kepada Liah.

Sikap percaya berkembang apabila setiap komunikasi menganggap komunikan lainnya berlaku jujur. Tentu saja sikap ini dibentuk berdasarkan pengalaman kita dengan komunikan. Karena sikap percaya berubah-ubah tergantung kepada komunikan yang dihadapi. Selain pengalaman, ada tiga faktor utama yang dapat menumbuhkan sikap percaya atau mengembangkan komunikasi yang didasarkan pada sikap saling percaya, yaitu: menerima, empati dan kejujuran. Dapat dikatakan bahwa daya tarik dan keahlian serta faktor pendukung kredibilitas tenaga perpustakaan saling berhubungan, keahlian tenaga perpustakaan penting kaitannya untuk menunjang daya tarik 
tenaga perpustakaan dari segi perpustakaan. Begitupun dengan daya tarik yang merupakan kesan pertama siswa kepada tenaga perpustakaan dan perpustakaan memiliki efek jangka panjang untuk keberlangsungannya berada di perpustakaan. Dari kedua komponen tersebut, yakni daya tarik dan keahlian apabila telah melalui waktu yang cukup panjang akan menimbulkan kepercayaan kepada tenaga perpustakaan oleh para siswa. Dan kepercayaan sendiri merupakan ujung tombak kredibilitas seseorang termasuk tenaga perpustakaan. Karenanya, dalam bagan tersebut, kredibilitas merupakan hasil akhir dari saling terkaitnya daya tarik dan keahlian tenaga perpustakaan yang menghasilkan kepercayaan sehingga kredibilitas tersebut dapat dimunculkan.

\section{SIMPULAN}

Berdasarkan paparan di atas, maka penelitian ini dapat ditarik simpulan sebagai berikut:

1) Daya tarik tenaga perpustakaan SMAN 1 Sindang terdiri dari dua faktor; faktor internal berupa penerapan teknik instruksional dan human relations dalam berkomunikasi dengan siswa yang menghasilkan hubungan interpersonal dan open communication (keterbukaan) di kedua pihak. Sedangkan faktor eksternal merupakan kegiatan promosi perpustakaan berupa pemberian reward kepada peminjam dan pengunjung terbaik serta sosialisasi perpustakaan yang rutin dilakukan kepada siswa baru SMAN 1 Sindang
2) Keahlian tenaga perpustakaan SMAN 1 Sindang secara keseluruhan meliputi kegiatan; pengelolaan, pelayanan, pengembangan sistem ketenaga perpustakaan yang dilihat dari kompetensi manajerial, kompetensi pengelolaan informasi, kompetensi kependidikan, kompetensi kepribadian, kompetensi sosial dan kompetensi pengembangan profesi

3) Latar belakang pendidikan yang berbeda semakin memotivasi tenaga perpustakaan SMAN 1 Sindang untuk saling bekerjasama dan menggabungkan keilmuan dan pengalaman keduanya untuk memaksimalkan fungsi perpustakaan SMAN 1 Sindang

4) Kepercayaan terhadap tenaga perpustakaan SMAN 1 Sindang muncul karena dibangun secara terus-menerus melalui daya tarik dan keahlian yang dimiliki oleh tenaga perpustakaan SMAN 1 Sindang. Kepercayaan dapat ditumbuhkan dengan sikap saling percaya, menerima, empati dan kejujuran

5) Kredibilitas tenaga perpustakaan di SMAN 1 Sindang turut dipengaruhi oleh faktor tingkat pendidikan, pengalaman, dan gaya komunikasi. Kepercayaan menjadi salah satu bentuk penilaian hasil akhir untuk kemampuan seorang tenaga perpustakaan terhadap perpustakaan yang dikelolanya. 


\section{DAFTAR PUSTAKA}

Anne. (2015). Reward Perpustakaan. (Tursi, Interviewer)

Ayu. (2015). Reward Perpustakaan. (Tursi, Interviewer)

Effendy, O. U. (2009). Human Relation \& Public Relation. Bandung: Mandar Maju.

Erna. (2015). Reward Perpustakaan. (Tursi, Interviewer)

Liah. (2015). Reward Perpustakaan. (Tursi, Interviewer)

Rakhmat, J. (2008). Psikologi Komunikasi. Bandung : Rosda.
Sapta. (2015). Reward Perpustakaan. (Tursi, Interviewer)

Saptarini. (2016). Pengembangan Perpustakaan. (Tursi, Interviewer)

Sugiyono. (2008 ). Memahami Penelitian Kualitatif. Bandung: Alfabeta.

Venus, A. (2009). Manajemen Kampanye. Bandung : Simbiosa Rekatama Media.

Yin, R. K. (2011). Studi Kasus Desain \& Metode. Jakarta : RajaGrafindo Persada.

Yusuf, P. M. (2010). Komunikas iInstruksional. Jakarta: Bumi Aksara. 